\title{
Studying Subsidence Coefficient of Mirages and Dynamic Storage Volume of Karstic Springs of Khorram Abad, West of Iran
}

\author{
Vidafar Milad*, Mohamad Reza Ahmadipour, Reza Zarei Sahamiyeh \\ Islamic Azad University Science and Research Branch, Tehran, Iran \\ Email: *m.vidafar1987@gmail.com
}

Received 22 May 2016; accepted 19 June 2016; published 22 June 2016

Copyright (C) 2016 by authors and Scientific Research Publishing Inc.

This work is licensed under the Creative Commons Attribution International License (CC BY). http://creativecommons.org/licenses/by/4.0/

(c) (i) Open Access

\begin{abstract}
The studied subject is about subsidence coefficient of mirages and dynamic storage volume of Karstic springs in Khorram Abad in West of Iran. Subsidence coefficient indicates ability of groundwater discharge and hydrologic properties of the environment; meaning effective porosity and transfer coefficient of springs. In general, in developed Karstic zones, each direct line of subsidence curve indicates a discharge regime. Obtained results from the study show that subsidence branch of Golestan, Motahari, Niloofar (changaei), Navekech, Dore Robat mirages have subsidence coefficient with mild slope and low value, which demonstrate passage of water through a seams system at the karst springs. $Q$ and whirlpool stone mirages have two subsidence coefficients, which indicate passage of water through two seam systems in Karstic environment of springs. According to obtained results, process of changes in subsidence branch in these mirages has had at the first a mild slope and low discharge coefficient and in continue, its discharge would be declined with sharper slope and high discharge coefficient. In order to estimate dynamic storage volume of springs, MAILET general equation is applied, which is suitable for subsidence branch of hydrographs of centralized springs discharge. Following, dynamic storage volume of studied springs is analyzed and obtained results are presented in this study respectively.
\end{abstract}

\section{Keywords}

Subsidence Coefficient, Mirage, Dynamic Storage, Karstic Springs, Khorram Abad

\section{Introduction}

Iran is a dry land with inadequate atmospheric descending, annual rainfall is approximately $250 \mathrm{~mm}$ that is less *Corresponding author.

How to cite this paper: Milad, V., Ahmadipour, M.R. and Sahamiyeh, R.Z. (2016) Studying Subsidence Coefficient of Mirages and Dynamic Storage Volume of Karstic Springs of Khorram Abad, West of Iran. Open Journal of Geology, 6, 372-375. http://dx.doi.org/10.4236/ojg.2016.66032 
than Asian average and is approximately one-third of rainfall average in the world. So, use of underground water resources has been considered for many years [1]. As an active orogeny, the Zagros Mountains are evolving through the convergence of the Arabian and Eurasian plates [2] [3]. The Zagros Orogen is formed by continental collision between the Afro-Arabian continent and the Iranian microcontinent in Late Cretaceous to Tertiary time. The Zagros zone is considered an important seismotectonic element for ages because of oil traps [4].

Being the largest reserve of drinkable water for human population, groundwater has always been of major importance to human civilization. Compared with other kinds of water, groundwater is normally preferred because it tends to be less contaminated directly by wastes and organisms [5]. About $65 \%$ of the country's water supply is reliant on groundwater or artificial groundwater, mostly derived from shallow, unconfined, unconsolidated springs [6]. The continuing population growth in Iran is rapidly depleting groundwater supplies in some areas. Rapid industrialization and urbanization have resulted in the degradation of soil and groundwater and resulted in a shortage of water resources of good quality in arid and semi-arid zones [7].

Geographically, the studied area with area over $1000 \mathrm{~km}^{2}$ is located between longitude of 48 degrees, $21 \mathrm{mi}-$ nutes and 48 degrees 12 minutes and latitude of 33 degrees and 34 minutes, 33 degrees and 36 minutes. In terms of geographical divisions, it is in limit of Lorestan Province and Khorram Abad City. The zone includes two main rivers named Sezar and Khorram Abad that are very important. The main purpose of this study is to investigate subsidence coefficients of mirages and hydrodynamic volume of karstic springs in Khorram Abad.

\section{Methodology}

Basically, karstic springs have two types of dynamic and static storage volume. In this study, two components of subsidence coefficient of mirages and dynamic volume of springs are evaluated. According to source equation (Equation (1)), with a discharge coefficient after tracing the discharge subsidence branch of the mirage during dry period of water year 2002-2003, its dynamic volume is estimated. The estimation is done suing diagram in Figure 1. Damping time of mirages is estimated in Equation (2).

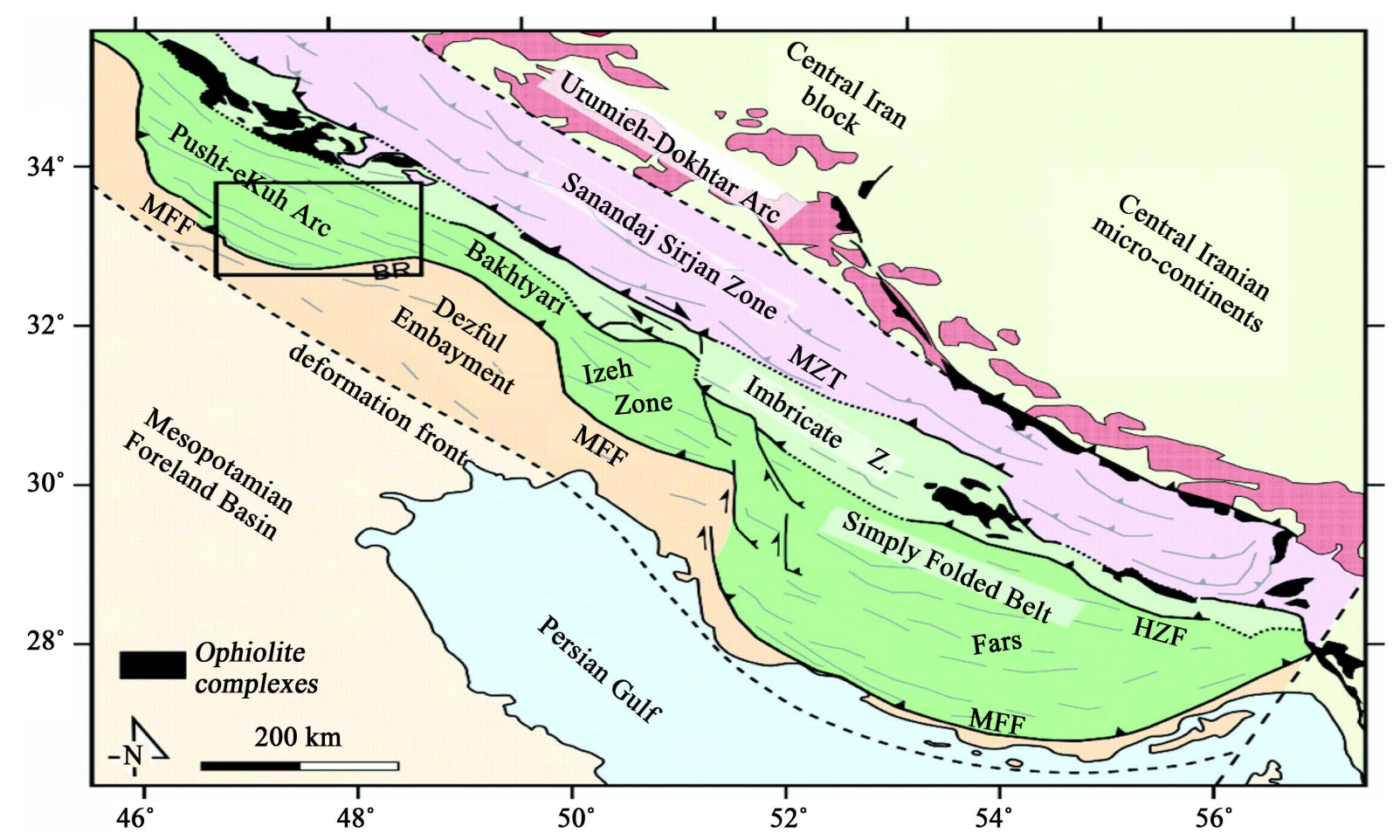

Figure 1. Zagros orogen in NW Iran and NE Iraq (Kurdistan area).Abbreviations: HZF-High Zagros Fault; KF-Kermanshah Fault; KHF-Khaneqin Fault; MF-Marekhil Fault; MFF-MountainFront Fault; MZT-Main Zagros Thrust. Line A-F is the location of the regional cross section presented in Figure 1. The inset shows location of the studied area on the geodynamic map of the Zagros. Arrows indicate GPS velocities from McClusky et al. [3] and Vernant et al. [2]. 


$$
\begin{gathered}
V=\frac{Q_{0}}{\alpha} e^{-\alpha\left(t-t_{0}\right)} \\
t=\left(\log Q_{0}-\log Q_{1}\right)
\end{gathered}
$$

\section{Discussion and Results}

Damping time of mirage is equal to 504 days regarding minimum discharge equal to $10 \mathrm{~L} / \mathrm{sec}$ in case of lack of power supply. Damping time of whirlpool stone mirage in case of lack of power supply is equal to 90 days. Dynamic storage volume of Golestan mirage to the end of water year is equal to $3.9 \mathrm{million} \cdot \mathrm{m}^{3}$ and its damping time has been equal to 0.4343 . Dynamic storage volume of Motahari mirage at the end of water year of Niloofar (changaei) is equal to 3.9 million $\mathrm{m}^{3}$. The value has been equal to 0.58 for Niloofar (changaei) mirage and in case of lack of power supply; it is equal to 283 days. Dynamic storage volume of Navekesh, Dore and Robat is also respectively equal to 7.5, 0.2 and 0.25 million $\cdot \mathrm{m}^{3}$ and the damping time for them is respectively to 909,129 and 129 days in case of lack of power supply. Among 8 studied mirages, Q and Robat mirages have highest discharge and Dore has the lowest discharge level. Mirages of Motahari, Golestan, Niloofar (changaei), Navekesh, Dore and Robat have less statistical changed during statistical period. However, discharge changes of Q and whirlpool stone mirages are abundant. Robat mirage is in kind of fault and others are overflow mirages. However, discharge changes of Motahari mirage are similar to Golestan and Dore is similar to Navekesh. This is because; in terms of geographical location, they are adjacent to each other and are discharged from a unit formation with same seam system. Type of mirages is overflow. Although Q and Whirlpool stone mirages are discharged from two springs, they have similar discharge changes. This is because; both of them are overflow and have springs with limited range and their seam system in Karstic environments is same. Their height is also higher than other mirages inside the city of Khorram Abad. Process of discharge changes of Robat mirages is different from other mirages. This is because; geographical location, seam system and type of rainfall affecting the Robat mirage are different from other mirages. The type of the mirage is fault. As Niloofar (changaei) mirage is located in Southern flank of the anticline of SefidKooh, it has independent discharge changes. Subsidence coefficient of mirages of Golestan, Motahari, Niloofar (changaei), Navekesh, Dore and Robat indicate passage of water through a seam system in karstic environment of springs. Mild slope of subsidence branch and low ratio of maximum to minimum indicates large storage of springs and continuity of discharge of the mirages. Discharge coefficients of Q and Whirlpool stone mirages indicate two seam systems in Karstic environment. High maximum-minimum discharge ratio of the mirages also refers to restricted springs and low storage volume. Process of their subsidence branch changes with discharge coefficient has gradual reduction and then the discharge would be declined with sharp slope and high discharge coefficient during short time. This is because; it seems that seam system of their karstic environment in beginning of the springs is in form of large channels; although in limit of sample, the system is in form of small channels and fine and linked pores. Accordingly, first the existing water in seam system close to sample is discharged and then, the water inside the seam system at the beginning of springs is discharged. Through investigation of discharge regime and comparison of mirages of the studied area, respectively, Q mirage has highest dynamic volume but shortest durability. After that, Golestan, Navekesh, Motahari and Robat mirages with longer durability; Whirlpool stone mirage with short durability; Niloofar (changaei) with good durability and Dore mirage with shortest dynamic volume but good durability have possessed next positions respectively. Among the mirages, Robat has completely separated springs; although springs of other mirages are Anticline of Khorram Abad. Although Q mirage indicates highest discharge level, it seems that its springs are under effect of influence of waters of Sarvak Formation of Sefidkooh in addition to existing waters in it. According to the mentioned and through considering estimated durability in case of continuity of dry period in short-term, Q and whirlpool stone mirages would have no discharge and dried period mirages would be durable about a year and a half and Navekesh would be durable about two years and a half to reach lowest discharge level.

\section{References}

[1] Khanlari, G.R. and Malmir, H. (2009) The Engineering Geology Evaluation of Rock Masses in Saraby Dam. 5th National Conference of Geology, Payame Noor University, Mashhad.

[2] Vernant, P., Nilforoushan, F., Hatzfeld, D., Abassi, M., Vigny, C., Masson, F., Nankali, H., Martinod, J., Ashtiani, A., Bayer, R., Tavakoli, F. and Chery, J. (2004) Contemporary Crustal Deformation and Plate Kinematics in Middle East 
Contained by GPS Measurements in Iran and Northern Oman. Geophysical Journal International, 157, 381-398. http://dx.doi.org/10.1111/j.1365-246X.2004.02222.x

[3] McClusky, S., Balassanian, S., Barka , A., Demir, C., Ergintav, S.,Georgiev, I., Gurkan, O., Hamburger, M., Hurst, K., Kahle, H., Kastens, K., Kekelidze, G., King, R., Kotzev, V., Lenk, O., Mahmoud, S., Mishin, A., Nadariya, M., Ouzoums, A., Paradissis, Y.P., Prilepin, M., Reilinger, R., Sanli, I., Seeger, H., Tealeb, A., Toksoz, M.N. and Veis, G. (2000) Global Positioning System Constraints on Plate Kinematics and Dynamics in the Eastern Mediterranean and Caucasus. Journal of Geophysical Research, 105, 5695-5719. http://dx.doi.org/10.1029/1999JB900351

[4] Jarahi, H., Naraghiaraghi, N. and Nadalian, M. (2015) Persian Gulf Fault: New Seismotectonic Element on Seabed. Canadian Journal of Basic and Applied Sciences (CJBAS), 3, 85-92.

[5] Tariq, S.R., Shah, M.H., Shaheen, N., Jaffar, M. and Khalique, A. (2007) Statistical Source Identification of Metals in Groundwater Exposed to Industrial Contamination. Environmental Monitoring and Assessment, 138, 159-165.

[6] Heikkinen, P.M., Korkka-Niemi, K., Lahti, M. and Salonen, V.P. (2002) Groundwater and Surface Water Contamination in the Area of the Hituranickelmine, Western Finland. Environmental Geology, 42, 313-329. http://dx.doi.org/10.1007/s00254-002-0525-z

[7] Jalali, M. (2007) Assessment of the Chemical Components of Famenin Groundwater, Western Iran. Environmental Geochemistry and Health, 29, 357-374. http://dx.doi.org/10.1007/s10653-006-9080-y

\section{Submit or recommend next manuscript to SCIRP and we will provide best service for you:}

Accepting pre-submission inquiries through Email, Facebook, Linkedin, Twitter, etc A wide selection of journals (inclusive of 9 subjects, more than 200 journals)

Providing a 24-hour high-quality service

User-friendly online submission system

Fair and swift peer-review system

Efficient typesetting and proofreading procedure

Display of the result of downloads and visits, as well as the number of cited articles

Maximum dissemination of your research work

Submit your manuscript at: http://papersubmission.scirp.org/ 